\title{
YAPAY ZEKA BAĞLAMINDA YARATICILIK VE GÖRSEL TASARIMIN GELECEĞİ
}

\author{
IN THE CONTEXT OF ARTIFICIAL INTELLIGENCE CREATIVITY AND THE FUTURE \\ OF VISUAL DESIGN
}

\author{
Burak KARABULUT ${ }^{1}$
}

Öz

Bilgi ve teknolojinin gelişimiyle ortaya çıkan yapay zeka uygulamalarını tasarım endüstrisinde görmekteyiz. Bu tür uygulamalar görsel tasarım alanında da gözlemlenmektedir. Yaratıcılık unsuru barındıran bir süreç olan görsel tasarımın, gelecekte bilgisayarların büyük veri işleyerek makine öğrenmesine dayalı tasarımların nasıl üretilebileceği ve nelere yol açabileceğinin tartışılması çalışmanın temel problemlerinden birini oluşturmaktadır. Diğer taraftan yapay zekanın insana ihtiyaç duymaksızın bir yaratım sürecine girip giremeyeceği durumunun, tasarıma olan etkisinin neler olacağı da başka bir problem olarak karşımıza çıkmaktadır. Çalışmanın çıkış noktası ve ele aldığ konu itibariyle görsel tasarımın yapay zekayla olan birlikteliği konusunda tasarımın geleceğine ilişkin öngörüler sunmak, bu birlikteliğin ardından yaşanacak sürecin nelere yol açabileceğini ortaya koymak bu çalışmanın temel amacıdır. Bu nedenle çalışmanın kavramsal çerçevesinde yapay zekanın yaratııılıkla ilişkisi incelenerek ikisi arasındaki etkileşimin oluşturduğu çeşitli örnekler verilmiş ve ardından teoriler üzerinden betimsel bir analiz yapılmıştır. Makine belirli bir şablon ve planlama sonucu elde edilen kalıpları öğrenebilmektedir. Fakat bireyin zekasının asimetrik yapısına, duygulara, sosyokültürel ve toplumsal faktörlere sahip değildir. Bu tür faktörler olmaksızın yapay zekanın gelecekte tasarım sürecine etkisinin neler olabileceği üzerine tartışılmaktadır.

Anahtar Kelimeler: Yapay Zeka, Makine Öğrenmesi, Yaratıcılık, Görsel Tasarım

\begin{abstract}
In the design industry, we see the artificial intelligence applications which come into being along with the development of information and technology. Such applications are observed in the area of visual design as well. Discussing the visual design that is a process including the element of creativity, how designs can be produced on the basis of the machine learning of computers by processing big data and what these designs will lead to in the future makes up one of the questions of the study. On the other hand, what the effects of the likely scenario that the artificial intelligence can take on the creation process with no need for human beings will be on the design also confronts us as another question. The primary aim of this study is to present projections in relation to the future of the design on the topic of the partnership of visual design with artificial intelligence in terms of the departure point of the study and issues addressed by study and to reveal what the process to be experienced following this partnership will lead to. Therefore, in the conceptual framework of the study, by examining the relationship of artificial intelligence with creativity, various examples created by the interaction between the two are given, and then a descriptive analysis is made through theories. The machine is capable of learning the patterns obtained through a specific template and planning. However, it does not have the asymmetric structure, emotions, cultural and societal factors of the human intelligence. What the effect of the artificial intelligence will be on the design process without such factors in the future is discussed.
\end{abstract}

Keywords: Artificial Intelligence, Machine Learning, Creativity, Visual Design

\footnotetext{
${ }^{1}$ Dr. Öğr. Üyesi, Hatay Mustafa Kemal Üniversitesi İletişim Fakültesi, karabulutbu@gmail.com, Orcid :0000-00034838-6064
}

Makale Türü: Araştırma Makalesi - Geliş Tarihi: 25.12.2020 - Kabul Tarihi: 05.04.2021

DOI:10.17755/esosder.844536

Atıf için: Elektronik Sosyal Bilimler Dergisi, 2021;20(79): 1498-1520 


\section{Giriş}

Becer (2015: 32) tasarım faaliyetini, "belirli bir amaç gözeten yaratıcı bir eylemdir" şeklinde yorumlamaktadır. Bu yorumdan yola çıkarak tasarım, ilgili probleme yönelik belirli bir planlama dahilinde, yaratıcılık yetisi kullanılarak çözüm yolları geliştirmenin amaçlanması olarak tanımlanabilir. Görsel tasarım içinse, toplumsal kabul gören bir takım sembol ve imgeler aracılığıyla oluşturulan görüntülerle belirli kurallar gözetilerek elde edilen çıktılar olduğu söylenmektedir. Görsel tasarımın tarihsel gelişimine bakıldığında çeşitli yöntem ve uygulamaların, teknolojinin gelişimiyle birlikte yaşanan dijital dönüşümden etkilendiği görülmektedir. Yaşanan dönüşümün oluşturduğu araç ve uygulamaların görsel tasarımla olan ilişkisinde yaratıcılık unsurunun her daim var olması, tasarımı tasarım yapan etkenlerin başında gelmektedir.

Teknik araçlar, çağlar öncesindeki en ilkel aletlerden günümüzdeki en gelişmiş makineler ve bilgisayarlara kadar geniş bir tasarım yelpazesini içermektedir. Görsel tasarım ise, günümüz tekniğinin olanaklarını kendi üretim yöntemlerine uygularken, bilim ve endüstrinin ilişkisinden doğan çıktıların oluşturduğu yeni soruları beraberinde getirmektedir. 1950 yılında Turing'in “makineler düşünebilir mi?” sorusuyla başlayan yapay zeka serüveni ise, tekniğin şu anda geldiği en üst nokta olarak nitelendirilmekte ve birçok disiplin için yeni düşüncelerin oluşmasına ve beraberinde yeni soruların sorulmasına neden olmaktadır. Yapay zeka uygulamalarıyla hayatın her alanında karşılaştığımız bu dönemde, tekniğin giderek eklemlendiği görsel tasarım mecrası da kendi payına düşeni almaktadır. Makine öğrenmesiyle veri işlemeye dayalı üretim süreçleri artık görsel tasarımı da etkilemektedir. Dolayısıyla bu çalışmanın temel problemini yapay zekanın, yaratıcılık unsurunun başat olduğu görsel tasarım alanına etkisinin ne olacağı sorusu oluşturmaktadır.

Günümüzde yapay zekanın algoritmalar aracılığıyla oluşturduğu çeşitli görsel çıktılar mevcuttur. Fakat yapay zekanın kendi içerisinde gelişimiyle ilgili araştırmacılarında çeşitli ön görüleri söz konusudur. Bahsedilen öngörülerin gerçekleşmesinin görsel tasarım alanına olan etkisinin neler olabileceği, bir insan yetisi olan yaratıcılık unsuruyla olan ilişkisinin nasıl şekilleneceği, yaratıcılık sürecinde bir kişinin yerini alıp alamayacağı gibi sorular tartışılmaktadır. 20. yüzyılın ortalarına gelindiğinde, kişisel bilgisayarların yayılmasıyla birlikte bilgi ve iletişim teknolojileri kullanılarak oluşturulan deneysel tasarım çalışmaları görsel tasarım alanında da etkili olmaktadır. Yaşanan bu değişim, tasarımcının dijital teknolojilere olan yetkinliğini gerektiren ve yeni uygulamalara olan yatkınlığını da beraberinde getirmektedir. Görsel tasarımı içeren yaratıcılık unsurunun yanında teknik ve bilimle olan etkileşiminden kaynaklanan yeni oluşumlar, aynı zamanda tasarımın oluşabilmesi için teknik sorgulamalara yol açarak bilimsel ve teknolojik gelişimi de sağlamaktadır. Diğer taraftan hayatın akışı içerisinde yer alan dijital sistem ve uygulamalar bireyin etrafını saran simülasyonlara neden olmaktadır. Bugün yapay zeka ve siber uzam gibi kavramlarla tanışan 21. yüzyılın bireyi için gerçeklik kavramı geçmiş dönemlerden çok daha farklı bir anlam ifade etmektedir. Artık bireyin bulunduğu simülasyon evreninde gerçekle imge arasındaki fark yok olmakta, yerini kodlar ve algoritmaların oluşturduğu sistemler almaktadır. $\mathrm{Bu}$ sistemler rasyonel gerçekliğin yerini alarak Jean Baudrillard'ın simülasyon kuramında ileri sürdüğü hiper-gerçeklik kavramına karşılık gelen ve görsel algının yönetimini, kontrolünü içeren dijital görselleştirmenin bir sonucu olarak karşımıza çıkmaktadır (Baudrillard, 2011: 44-45).

Öte yandan günümüz iletişim kuramlarına da temel olan ve 1948 yılında Claude E. Shannon tarafindan yayınlanan 'Enformasyon Kuramı' bilgisayarlarla yaratılan estetik ürünlerle 
ilgili çalışmaların temelini oluşturmaktadır. Bilgisayarlar aracılığıyla bilgi işlemeye dayalı bilimsel ve estetik görüntüyü oluşturmaya yönelik işlevsel, teknik ve estetik değerlerin dikkate alınarak oluşturulduğu bir kuramdır (Shannon, 1948: 105-106). Bu bakımdan yapay zekanın yaratıcılık unsurunu barındırmasıyla ilgili değerlendirmenin yanında Enformasyon Kuramı ve Simülasyon Kuramıyla ilişkilendirilerek görsel tasarım ürünlerinde ortaya konulan yaratı da tekniğin izlerinin neler olduğu ve bununla ilişkili yapay zeka çıktılarının toplumsal hayata etkilerinin tartışılması hedeflenmektedir.

\section{Yapay Zeka Nedir?}

Yapay zeka kavramı genel olarak makinenin akıllı davranışlar sergileyebilmesidir. Akıllı davranışsa sırasıyla algılama, akıl yürütme, öğrenme, iletişim kurma, karışık ortamlarda hareket etmeyi kapsamaktadır. Uzun vadede yapay zekanın hedefi insanların yapabileceği şeyleri en az onlar kadar hatta onlardan daha iyisini yapabilen makineler geliştirmektir (Nilsson, 1998: 9). Diğer bir tanımda ise Luger ve Stubblefield (1998: 1), yapay zekayı "akıllı davranışın otomasyonu ile ilgilenen bilgisayar biliminin dalı" olarak tanımlamaktadır.

İlk olarak yapay zeka kavramı 1956 yılında Darthmouth’ta, alanla ilgili çeşitli araştırmalar yapan bir grup araştırmacının çalışmalarının ardından, John McCarthy tarafından ifade edilmiştir (Russell ve Norvig, 2010: 17). Yapay zekayı "akıllı makineler yapma bilimi ve mühendisliği" şeklinde tanımlayan McCarthy (2007: 2-4), sürecin İkinci Dünya Savaşı sonrasında birkaç kişinin bağımsız olarak akıllı makineler üzerinde çalışmaya başlayarak geliştiğini ve İngiliz matematikçi Alan Turing'in bunlardan ilki olabileceğini belirtir.

Alan Turing, 1950 yılında "makineler düşünebilir mi?" sorusuyla başladığg Computing Machinery and Intelligence adlı çalışmasında, bu sorunun cevabını vermek için "makine" ve "düşünme" terimlerinin tanımını yaparak bulunamayacağını, onun yerine Imitation Game adını verdiği bir test ile tanımlayabileceğini ifade etmektedir (Turing, 1950: 433). Turing testi olarak da bilinen bu testte bir insan ve bir bilgisayar, deneyi yapan sorgulayıcıdan gizlenir. Deneyi yapan hangisiyle haberleştiğini bilmeden bunların ikisiyle de haberleşir. Sorgulayıcının sorduğu sorular ve deneklerin verdiği cevaplar bir ekranda yazılı olarak verilir. Bu testte amaç, deneyi yapan bireyin uygun sorgulama ile deneklerden hangisinin insan, hangisinin bilgisayar (makine) olduğunu bilmesidir. Eğer deneyi yapan birey güvenilir bir şekilde bunu söyleyemez ise, o zaman bilgisayar Turing testini geçer ve insanlar kadar kavrama yeteneğinin olduğu varsayılır (Pirim, 2006: 90). Bu testte bir makinenin bir insanı yanıltıp yanıltamayacağı sorusunun cevab1 aranmaktadır. Eğer bir makine, deneyi yapan bireye insanmış gibi davranabilirse o makine insanlar kadar akıllıdır savının tespit edilmeye çalışıldığı bir test olduğunu söyleyebiliriz. Özetle; insana özgü olan, zekanın ürün ve fonksiyonlarının makinelere kazandırılıp kazandırılamayacağı amaçlanmaktadır.

Diğer taraftan Alan Turing'in yaptığı bu çalışmanın yanı sıra bu dönemde Waren Mc Culloch ve Walter Pitts basit hesaplama yöntemleri ile biyolojik nöronlar arasındaki ilişkiyi araştırırken, Frank Rosenblatt ise öğrenme ve şekil tanıma için nöron benzeri elementlerin algılamasında ağların kullanımıyla ilgili çalışmalar yapmaktaydı. Ayrıca başka araştırmacıların bilişsel psikoloji, hesaplanabilir dilbilim ve uygulamalı kontrol teorisi gibi alanlarda yapmış olduğu birçok çalışmada yapay zekanın gelişimine katkıda bulunmuştur (Nilsson, 1998: 9).

Russel ve Norving (2010: 1021) ise, Turing testine eleştirel bir bakış açısıyla yaklaşarak dezavantajları olduğunu belirtmektedirler. Test için bir programın beş dakika boyunca bir sorgulayıcıyla çevrimiçi yazılan mesajlar yoluyla sohbet etmesi planıyla hareket ettiğini ve 
programın, sorgulayıcının zamanın \%30’u kadar kandırırsa testi geçeceğini ifade etmektedirler. Ayrıca daha güçlü depolama alanına sahip bir bilgisayarın, testi geçecek kadar iyi programlanabileceğini tahmin ettiklerini ancak programın ya da makinenin henüz konusuna hakim bir uzmanı kandıramadığını belirtmektedirler. Diğer taraftan Russel ve Norving (2010: 23), bir bilgisayarın Turing testini geçebilmesi için yapması gerekenleri aşağıdaki gibi siralamaktadır:

Doğal dil işleme: İngilizce ile başarılı bir şekilde iletişim kurabilme.

Bilgi gösterimi: bilgisayarın bildiklerini veya duyduklarını depolaması.

Otomatik akıl yürütme: depolanan bilgileri soruları cevaplamak ve yeni sonuçlar çıkarmak için kullanmak.

Makine ögrenimi: yeni koşullara uyum sağlamak, kalıpları tespit etmek ve tahmin etmek.

Bilgisayar vizyonu: nesneleri algılaması için gereken görme yetisi

Robotik: nesneleri manipüle etmek ve hareket etmek.

Russel ve Norving, bir bilgisayarın Turing testini geçmesi gereken bu 6 etken için aynı zamanda yapay zeka sisteminin neredeyse tamamını oluşturduğunu belirmektedirler. Russell ve Norvig (2010: 2-5), yapay zekayı konuyla ilgili düşünürlerin tanımlamalarından yola çıkarak birbiriyle ilişkili 4 farklı ana başlık oluşturarak tanımlamaya çalışmış olup, aşağıdaki gibi sınıflandırmıştır:

Tablo. 1 Stuart Russel ve Peter Norvig'e göre Yapay Zeka Sınıflandırması

\begin{tabular}{|c|c|}
\hline İnsan gibi düşünen sistemler & Rasyonel düşünen sistemler \\
\hline $\begin{array}{l}\text { Düşünen bilgisayarlar konusundaki heyecan } \\
\text { verici yeni çabalar... tam anlamıyla zihinsel } \\
\text { makineler (Haugeland, 1985) }\end{array}$ & $\begin{array}{l}\text { Hesaplama modellerinin } \\
\text { kullanımı yoluyla zihinsel } \\
\text { becerilerin incelenmesi (Charniak } \\
\text { \& McDermott, 1985) }\end{array}$ \\
\hline $\begin{array}{l}\text { İnsan düşüncesiyle ilişkilendirdiğimiz karar } \\
\text { verme, problem çözme, öğrenme gibi } \\
\text { aktivitelerin otomasyonu (Bellman, 1978) }\end{array}$ & $\begin{array}{l}\text { Algilama, akıl yürütme ve } \\
\text { hareket etmeyi mümkün kılan } \\
\text { hesaplamaların incelenmesi } \\
\text { (Winston, 1992) }\end{array}$ \\
\hline İnsan gibi davranan sistemler & Rasyonel davranan sistemler \\
\hline $\begin{array}{l}\text { İnsanlar tarafindan gerçekleştirildiğinde zeka } \\
\text { gerektiren işlevleri yerine getiren makineler } \\
\text { yaratma sanatı (Kurzwell, 1990) }\end{array}$ & $\begin{array}{l}\text { Hesaplamalı zeka kullanımı akıllı } \\
\text { davranışları açıklamak ve } \\
\text { tasarımının incelenmesidir (Poole } \\
\text { vd., 1998) }\end{array}$ \\
\hline $\begin{array}{l}\text { Şu anda insanların daha iyi olduğu şeyleri } \\
\text { bilgisayarların nasıl yapacağına dair çalışma } \\
\text { (Rich and Knight, 1991) }\end{array}$ & $\begin{array}{l}\text { Yapay zeka yapay olan akıllı } \\
\text { davranışlarla ilgilidir (Nilsson, } \\
\text { 1998) }\end{array}$ \\
\hline
\end{tabular}

Kaynak: Russell, S. ve Norvig, P. (2010). Artificial Intelligence: A Modern Approach, USA: Prentice Hall Series. 
Akın, (2008: 37), tabloyla ilgili sınıflandırmaları şöyle açıklamaktadır İnsan gibi düşünen sistemler: insanın bellek, zihin vb. düşünsel mekanizmalarını modelleme yöntemiyle yapay zeka sistemlerini geliştirmek hedefinde olanlar. Insan gibi davranan sistemler: siradan bir gözlemciye davranışları insandan farksız gelecek sistemlerin oluşturulması bu çalışmaların amacını oluşturmaktadır. Rasyonel düşünen sistemler: bu yöntemde rasyonellik, verilen bir durum için en doğru şey olarak tanımlanabilir. Bu çalışmalar, insanların rasyonel olmadığı kararlarının duyguları tarafından olumsuz şekilde etkilendiği varsayımından yola çıkarak "doğru düşünce nedir?" sorusuna yanıt ararlar. Rasyonel davranan sistemler: Herhangi bir durum karşısında enerji, bellek ve hesaplama kapasitelerine göre en doğru şeyi yapan sistemlerin oluşturulması yapılan bu araştırmaların ana amacını oluşturmaktadır (Akın, 2008: 37; Russell ve Norvig, 2010: $2-5)$.

Yarım yüzyılı aşkındır konuyla ilgili yapılan araştırmalar, çalışmalar ve uygulamaların sonucunda yapay zekanın kendi içerisinde 3 farklı evrede gelişim göstereceği sonucu çıkarılmaktadır. Bunlardan ilki yapay dar zeka (Artificial Narrow Intelligence ya da ANI) şeklinde ifade edilmektedir. Zayıf YZ (Weak AI) olarak da bilinen yapay dar zeka tek bir hedef, işlem ya da problemi çözmek için tasarlanmış sistemler olarak tanımlanmaktadır (Jajal, 2018). Yapay dar zeka sayesinde Facebook'un görüntülerdeki yüzleri tanımasını ve kullanıcıları etiketlemesini, Apple Siri'nin sesinizi anlamasını ve buna göre hareket etmesini ve Tesla firmasının kendi giden arabalar geliştirilmesi sağlanmıştır (Kaplan ve Haenlein, 2019: 2). Günlük hayatta sıkça kullanılan birçok teknolojik araçta, yapay dar zekanın sunduğu birçok imkândan yararlanılmaktadır. Böylelikle yapay zekanın insan hayatına olan etkisi ve toplumsal değişime olan katkısı gözlemlenmektedir.

Yapay zekanın ikinci evresi yapay genel zeka (Artificial General Intelligence ya da AGI) olarak ifade edilmektedir. Yapay dar zeka neslinden farkı ise, makinenin bilgi ve becerilerini farklı durum ve bağlamlarda uygulamasına izin vermesidir. Bu bağımsız öğrenme ve problem çözme becerisi yapay dar zekaya göre insan zekasına daha yakın niteliklere sahip olmasına neden olmaktadır (Davidson, 2019). Yapay genel zekanın sorunları çözmesi, belirsizlik altında karar vermesi, planlaması, öğrenmesi, önceki bilgileri karar alma sürecine entegre etmesi ve yenilikçi ve yaratıcı olması beklenmektedir. Fakat makinelerin gerçek insan benzeri zekayı elde edebilmeleri için, insana özgü bilinci deneyimleyebilmeleri gerekmektedir (Jajal, 2018). Bu versiyonun yapay dar zekaya kıyasla en önemli özelliğinin bir programlamacı olmaksızın kendi kendine öğrenebilme yetisi olacağı söylenebilir. Bu durum ise terminolojide derin öğrenme (deep learning) ifadesiyle adlandırılmaktadır. Derin öğrenme yine terminolojide geçen makine öğrenme (machine learning)'in bir alt alanını oluşturmaktadır. Derin öğrenme yeni bir yaklaşım olup semantik ayrıştırma, doğal dil işleme, bilgisayarla görme ve daha birçok geleneksel yapay zeka alanlarında yaygın olarak uygulanmaktadır (Guo vd., 2016: 27). Makine öğrenimi ise programcı vasitasıyla desen bulma, talimat, komut veya ön programlama yapılmaksizın sistemin kendi başına öğrenerek karar verme yeteneği olarak tanımlanmaktadır (Davidson, 2019). Derin öğrenmenin makine öğreniminin bir alt kolu, makine öğreniminin de görevleri gereğince yapay zekanın bir alt kümesi olduğu söylenmektedir.

Yapay zekanın son evresi olan süper yapay zekayla ilgili (Artificial Super Intelligence veya ASI) Oxford Üniversitesi'nden filozof Nick Bostrom "hemen hemen tüm ilgi alanlarındaki insanların bilişsel performansını büyük ölçüde aşan herhangi bir akıl" olarak tanımlamaktadır (Jajal, 2018). Süper yapay zeka Kaplan ve Haenlein, (2019: 2)'e göre ise “insanları gereksiz kılacak, gerçekten kendini tanıyan ve bilinçli sistemler" şeklinde yorumlanmaktadır. Bu 
sistemlerin yapay zekanın en ileri evresi olacağı, daha önceki sistemlerin sahip olmadığı bilince sahip bilimsel yaratıcılık, genel bilgi ve sosyal yeteneklerin de dahil olacağı ayrıca insanoğlundan daha zeki olacağı belirtilmektedir. Kaplan ve Haenlein, (2019: 2), yapay zekanın üç evresini Tablo. 2'deki gibi özetlemektedir.

Tablo. 2 Yapay Zekanın Aşamaları

\begin{tabular}{|c|c|c|}
\hline YAPAY DAR ZEKA & $\begin{array}{c}\text { YAPAY GENEL } \\
\text { ZEKA }\end{array}$ & YAPAY SÜPER ZEKA \\
\hline Zayıf - İnsan seviyesinin altında & $\begin{array}{c}\text { Güçlü - İnsan } \\
\text { seviyesinde }\end{array}$ & $\begin{array}{c}\text { Bilinçli / Kendini Tanıyan, } \\
\text { İnsan seviyesinin üstünde }\end{array}$ \\
\hline $\begin{array}{c}\text { Spesifik alanlarda uygulanan } \\
\text { sistemlerdir. }\end{array}$ & $\begin{array}{c}\text { Çeşitli alanlarda } \\
\text { uygulanan sistemlerdir. }\end{array}$ & $\begin{array}{c}\text { Herhangi bir alana } \\
\text { uygulanan sistemlerdir. }\end{array}$ \\
\hline $\begin{array}{c}\text { Otonom bir yapıdadır ve } \\
\text { programlamada verilen görevin } \\
\text { dişındaki sorunları çözemez. }\end{array}$ & $\begin{array}{c}\text { Bağımsız bir yapıdadır } \\
\text { ve programlamada } \\
\text { verilen görevin } \\
\text { dışındaki sorunları } \\
\text { çözebilir. }\end{array}$ & $\begin{array}{c}\text { Kendisine verilen görev } \\
\text { dişındaki sorunları anında } \\
\text { çözebilir. }\end{array}$ \\
\hline $\begin{array}{c}\text { Performans olarak insanlara eşit } \\
\text { ya da daha iyi performans } \\
\text { gösterir. }\end{array}$ & $\begin{array}{c}\text { Performans olarak } \\
\text { insanlara esit ya da } \\
\text { daha iyi performans } \\
\text { gösterir. }\end{array}$ & $\begin{array}{c}\text { Her alanda insanları geride } \\
\text { bırakıyor. }\end{array}$ \\
\hline
\end{tabular}

Kaynak: Kaplan, A. ve Haenlein, M. (2019). "Siri, Siri, in My Hand: Who's the Fairest in the Land? On the Interpretations, Illustrations, and Implications of Artificial Intelligence", Business Horizons, 62(1), s.15-25.

Günümüze kadar çeşitli yapay zeka algoritmalarıyla yazılmış birçok uygulamayı görmekteyiz. Bunların başında IBM firmasının tasarlamış olduğu Deep Blue adlı program gelmektedir. Deep Blue, 11 Mayıs 1997 tarihinde Dünya satranç şampiyonu Gary Kasparov’u mağlup etmiştir (McCorduck, 2004: 481). Yaşanan bu gelişmenin ardından yapay zekanın tarihsel sürecini değerlendirdiğimizde, 50'li ve 60'lı yıllarda bilgisayarlara bir takım bilişsel görevleri yerine getirmeyi amaçlayan ve insan zihninin yapabildiği birçok yetiyi sümile edebilen tasarımların geliştirilmeye çalışıldığı gözlemlenmektedir. Bunun ardından matematiksel problemleri çözmek, yazılı ve sözlü dili anlamak, görüntüleri tanımak gibi çeşitli görevleri üstlenebilen algoritmaların hayata geçirildiği görülmektedir.

Bugün yapay zekadan; tıptan, ekonomiye, iş dünyasından, tüketici karar süreçlerine, potansiyel suç unsurlarının tespitinden, savunma sistemlerine kadar birçok alanda emek ve zaman tasarrufu sağlayarak; verimli, kolay ve güvenilir bir şekilde faydalanılmaktadır. Ayrıca yapay zeka öngörülebilir bir hayatın, yaşamsal pratiklerin ve yeni üretim kalıplarının oluşmasını da sağlamaktadır. Bilgisayarlar artık sonsuz sayıda işlemi gerçekleştirerek gelecekte bireyin yaşamına etki edecek birçok unsuru tespit eder hale gelebilmiştir. Bu durumun gelecekle ilgili olası hesap, problem ve öngörülerin önceden bireyler tarafından kavranmasına ve kültürel yeni bir kırılmanın yaşanmasına neden olabileceği de ifade edilmektedir. Günümüzde farklı alanlarda kullanılan yapay zeka uygulamalarını ise aşağıdaki gibi sıralamak mümkündür (Cevher ve Aydın, 2020: 622-623): 
- Çevresiyle etkileşimde bulunan ve 100'den fazla sesle komuta yanıt veren Aibo isimli ilk robot köpek 1999 yılında geliştirilmiştir.

- $\quad$ Olası çarpışmalara karşı tepki veren, yürüyen ve merdiven çıkan ilk insansı robot ASIMO 2000 yilında üretilmiştir.

- Robotlar Mars’a 2004 yılında ayak basmıştır.

- 2005 yılına gelindiğinde Boston Dynamics şirketi RobotBigDog'u geliştirmiştir. Aynı yı1 otonom araçların katılabildiği bir yarışta beş takım, araçsız sürücüyle rotayı tamamlamayı başarabilmiştir.

- NASA 2010 y1lında insans1-astronot robot olan Robotnaut 2'yi üretmiştir. IBM firmasının geliştirmiş olduğu Watson adlı yapay zeka uygulamasıysa, Amerikan televizyon kanalında yayınlanan Jeopardy! adlı bilgi yarışmasında bütün yarışmacıları geride bırakarak bir milyon dolarlık bir hediye almış ve yine aynı yıl ilk 3D yazıcılar kullanılmaya başlamıştır.

- 2014 yılına gelindiğinde SoftBank firması tarafından geliştirilen insanlarla etkileşimde bulunan ve müşteri hizmetlerinde kullanılabilen Pepper adlı bir robot geliştirilmiştir.

- Dünyanın ilk akışkan otonom robotu 3D yazıcı kullanılarak 2016 yılında üretilmiştir.

$\mathrm{Bu}$ gelişmelerin yanı sıra Apple firmasının Siri, Google'ın sunduğu Cortana ve Amazon'un geliştirmiş olduğu Alexa uygulamaları da kullanıcıya özel kişiselleştirilmiş hizmet sunulması, aranan bilgiyi doğru ve hızlı ulaşılmasını sağlayan yapay zeka temelli yazılımlar olarak kullanıcılara sunmaktadır. Diğer taraftan The Grid firmasının yapmış olduğu Molly uygulamasıyla web site tasarımını oluşturması, Prisma Labs'ın geliştirdiği ve fotoğraf düzenlemesi için kullanılan Prisma, tasarımcılar için sevdiği renkleri öğrenerek ona uygun renk paletleri sunan Khroma uygulaması ya da imaj olarak tasarlanan web sitesi görselini HTML hale getiren tasarımcılara yönelik yapay zeka temelli algoritmik birçok uygulama bulunmaktadır.

Genellikle birçok uluslararası firma, şu an için yapay dar zeka diye adlandırılan modelle çeşitli çalışmalar yapıp, bunlarla ilgili ürünler geliştirip, ileri safha yapay zeka kavramlarıyla ilgili fikirler geliştirirken, diğer taraftan yapay zeka aracılığıyla çeşitli dallarda sanatsal estetiğe sahip ürünlerin yaratımıyla da ilgilenilmektedir. Bu durumun yapay zekanın en üst evresi olacağı ifade edilen yapay süper zekaların hayata geçmesiyle birlikte, şuan hali hazırda görmüş olduğumuz çeşitli görsel tasarım ürünlerinin üretim kalıplarına olan etkisini de arttıracağı düşünülmektedir. Dolayısıyla yapay zekanın görsel tasarıma olan etkisi noktasında insanoğlunun estetiksel yaratım sürecine etki eden "yaratıcılık" unsurunda farklılıklar yaşanacağı düşünülmektedir. Bu nedenle çalışmanın bu bölümünde "yaratıcılık" kavramının ne olduğu ve teknikle olan ilişkisi noktasında değerlendirme yapmak gerekmektedir.

\section{Yaratıcılıkta Tekniğin İzleri}

İlk çağ filozoflarından günümüze kadar tartışılan yaratıcılık kavramı psikolojiden felsefeye, güzel sanatlardan eğitime kadar birbirinden farklı disiplinler tarafından çeşitli fikir ve tanımlamalar yapılmaktadır. Türk Dil Kurumu resmi sözlüğüne göre "yaratma yeteneği” ve "her bireyde var olduğu kabul edilen, bir şeyi yaratmaya iten farazi yatkınlık" şeklinde tanımlanan yaratıcılık, genel olarak "az çok bir amaca yönelik, yeni ve orijinal fikirler, ürünler, bileşimler ortaya koyabilme” yeteneği olarak yorumlanmaktadır (Samurçay, 1983: 6). 
Becer (2015:47) yaratıc1lığ1 “kimsenin düşünemeyeceği şeyi düşünebilmek” ifadesiyle tanımlamaktadır. Yaratıcılığın süreç, özgün olmak, yeni olmak ve problem çözme noktalarını içeren bir olgu olduğunu belirten Al $(2019 ; 82)$, yaratıcılık hayal gücüne dayalı üretken düşünce ve davranışları içerirken, bu düşünce ve davranışların bir amaca yönelik özgün ve değerli çıktılarının olmasının yaratıcılığın karakteristik niteliklerini oluşturacağını ifade etmektedir. San (1979: 177) ise yaratıcılığ "her bireyde var olan ve insan yaşamının her bölümünde bulunabilen bir yeti, günlük yaşamdan bilimsel çalışmalara dek uzanan geniş bir alanı içine alan süreçler bütünü, bir tutum ve davranış biçimidir." şeklinde yorumlamaktadır. Yaratıcılık eyleminin bu yorumlardan da anlaşılacağı üzere hayatın her alanında gerek duyulan ve gözlemlenebilen bir nitelik olduğu söylenebilir.

Yaratıcılık kavramı hem bilişsel süreç hem de bir beceri faaliyeti olarak tanımlanmış, günlük hayatta sergilediğimiz eylemlerden; sanat, teknik ya da bilim gibi özel alanları da içine alan geniş kapsamlı bireyin yaptığı her eylemde karşımıza çıkabilen bir olgu olarak yorumlanmıştır (May, 2008: 64). Bu nedenle yaratıcılık, çözülmesi gereken problemle ilgili bireyin zihninde kimi zaman alternatif çözüm yolları bulunması noktasında uyarıcı bir faktör olurken kimi zaman da baskı nedeni olabilmektedir.

Gartenhaus (2000:15)'un yaratıcılıkla ilgili yorumu; “alışkanlık ve kanaat işlevlerinin ötesinde, kişisel keşif, değişim ve yüksek düzeyde anlayışa götüren fikirleri ve olasılıkları oluşturma becerisi" şeklindedir. E. Paul Torrance ve J. P. Guilford, yaptıkları araştırma sonucunda yaratıcı bireylerin düşünce ve fikirlerini inşa ederken en az dört temel yol izlediklerini gözlemlemiş ve bunları akıcılık, esneklik, özgünlük ve düzenleme olarak sınıflandırmışlardır. Bu dört etken yaratıcı olmanın tek yolu olarak ifade edilemeyeceğini; fakat bunlar yaratıcı düşünme örüntülerini anlamaya yönelik uygun kategorileri temsil edeceği ve bu etkenlerden her birinin ayrı olarak gerçekleşebileceği gibi tek bir kombinasyon halinde de oluşabileceği ifade edilmektedir. Bu dört temel etken aşağıdaki gibi açıklanmaktadır (Gartenhaus, 2000: 18-19):

Akıcılık: "Akıcı düşünme, olanaklar, fikirler ya da sonuçlar niceliği üretmek için kolaylıktır. Akıcı düşünürler oransız miktarda fikirler üretirler. Akıcı düşünürlerin çoğu zaman, yorucu gibi görünen bir tartışmadan uzun süre sonra bile "ekleyecek bir şeyleri daha" vardır."

Esneklik: "Esnek düşünme bakış açısında bir çeşitlilik geliştirme yeteneğidir. Esnek düşünürler, tek bir soruna pek çok yaklaşım yolu amaçladıkları için bir tür zihin jimnastiği gerçekleştirirler. Esnek düşünürler otoriteye meydan okuyabilirler, çünkü bir şey yapmanın "tek yol"unun kendi seçenekleri görürler."

Özgünlük: "Özgün düşünme, alışılmadık, benzersiz ya da yüksek derecede kişiselleşmiş yanıtlar ya da fikirler üretme yeteneğidir. Özgün düşünürler ve onların yeni yanıtları garip ya da katıksız biçimde kendine özgü görünebilir."

Düzenleme: "Düzenleyici düşünme fikirleri genişletme, geliştirme ve süsleme yeteneğidir. Düzenleyici düşünürler ayrıntılarla ve ayrıntılar tarafından büyülenirler. Yaptıkları şeydeki "doku"ya ve "zenginlik"e başka insanlardan daha fazla aldırış eden ya da dikkat eden bireyler gibi görünmektedirler. Düzenleyici düşünürler çoğu zaman karmaşık ve karışı şeylere yönelirler.” Bu dört temel etkenin problemlerin tespiti ve çözümüne yönelik fikir ve düşüncelerin oluşmasında; yaratıcı yetiye sahip bireyin bulundurması gereken önemli etkenlerden olduğunu söyleyebiliriz. Gartenhaus (2000)'un zihinsel sistematik farklılıklardan yola çıkarak oluşturduğu, yaratıcılıkla ilgili gruplamaların ardından zihinsel gelişimin geçmişteki kültürel deneyim ve bilgilerimizin yaratıcı olma konusunda etkili olduğu düşüncesi de önem arz etmektedir. 
Muhtemelen zihinde oluşan yeni fikirler tamamıyla yeni değildir, çünkü bu yeni fikirlerin tohumları zihinde olan temsillerdedir. Başka bir deyişle, kültürümüzün tohumları, tüm bilgi ve deneyimlerimiz, her yaratıcı fikrin arkasında yatan nedendir. Bilgi ve deneyim ne kadar fazla olursa, yaratıcı bir fikri oluşturma yolunda düşünülemeyen ilişkileri bulma olasılığ 1 da o kadar büyük olur. Biz yaratıcılığı sahip olduğumuz bilgi parçaları arasında yeni ilişkiler kurmanın sonucu olarak anlarsak, o zaman daha önce sahip olduğumuz bilgiler, daha yaratıcı olma kapasitemizin artmasını sağlar (Mántaras, 2017: 2; Boden, 1987). Bireyin yaşadıkları tecrübelerden edindiği bilgi ve deneyimlerin, hayat içerisindeki kültürel pratiklerden edinilen çeşitli bellek birikimlerinin yaratıcılık üzerinde etkisi olduğunu ifade edebiliriz.

Yaratıcılık; sorunlara, yetersizliklere, bilgi eksikliğine mevcut olmayan elemanlara, uyumsuzluklara karşı duyarlı olma, güçlükleri belirleme, çözümler arama tahminler yapma ve eksikliklerle ilgili olarak hipotezler kurma ya da hipotezleri değiştirme çözüm yollarından birini seçme ve deneme, yeniden deneme, daha sonra da sonuçları ortaya koymadır (Aslan, 2001: 18). Aslan'ın bu tanımından yola çıkarak yaratıcılık için aynı zamanda problemler karşısında gösterilen "yeni ve farklı bir ürün ortaya koymak için eylemde bulunmak" reaksiyonu olarak tanımlayabiliriz.

Yapılan çeşitli yorum ve değerlendirmelerin ardından, yaratıcılık yetisinin insanoğluna özgün bir olgu olduğunu ifade edebiliriz. Fakat günümüzde yapay zekanın da yaratıcı çözümler sunabildiği gözlemlenmektedir. Margaret Boden'in yaratıcılık kavramının makinelerle olan ilişkisini irdelediği The Creative Mind Myths an Mechanisms adlı eserinde yaratıcılık yetisinin insan aklının bir mucizesi olduğunu ifade ederek başlamakta ve yaratıcılığ "yeni, şaşırtıcı ve değerli olan fikir ya da eserler üretme yeteneğii" olarak tanımlamaktadır (2004: 1). Boden (2004: 3-6), aynı eserinde yaratıcılığ 1 üç farklı formda sınıflandırmaktadır. Bunlardan birincisi tanıdık, bilinen iki farklı fikrin kombinasyonlarını yapmayı içeren kombinasyonel (combinational) yaratıcılık biçimidir. Bu durumu birbirinden farklı iki fikrin birleşiminden oluşan yeni bir fikir üretimi için gereken kombinasyonun oluşturulması şeklinde açıklayabiliriz. İkincisi, kavramsal bir alanın araştırılmasının ardından yeni fikirlerin üretilmesini ifade eden keşfetmeye dayalı (exploratory) yaratıcılık şeklidir. Üçüncüsü ise dönüşümsel (transformational) yaratıcılık olarak ifade edilmekte ve kavramsal araştırma alanının dönüşümüne bağlı yeni fikir üretimlerini tanımlamaktadır.

Boden (2004: 6), keşifsel ve dönüşümsel yaratıcılığın nasıl olabileceğini anlamak için kavramsal alanların ne olduğunu ve ne tür zihinsel süreçlerin onları keşfedip değiştirebileceğini bilmek gerektiğini vurgulamaktadır. O, yaratıcılık yetisinin bireyin zihnindeki kavramsal alanların keşfini ve dönüşümünü içerdiğini belirtmekte ve kavramsal alanlar ifadesini yaratıcılık eyleminin temeline yerleştirmektedir. Kavramsal alanları ise bilgisayarları ilgilendiren ilk nokta olduğunu ve onları keşfetme ve dönüştürme yollarının yapay zekadan alınan kavramlarla tanımlanabileceğini belirtmektedir.

Boden (2004: 1), kavramsal alanlar terimiyle insan beyninde yaratıc1lık faaliyetinin gerçekleştiği soyut noktalara işaret etmektedir. Yapay zekanın sayısal kavramlar ve hesaplamaları kullanarak, yeni alanlar üretmek için bu soyut alanların nasıl dönüştürülebileceğini ifade etmektedir. Ayrica makinelerin belirli bir seviyeye kadar yaratıcı olabileceklerini bu durumu makine yaratıcılığı fikriyle ortaya koymaktadır.

Artık bu tanımlama ve değerlendirmelerin 1şı̆̆ında sormamız gereken sorunun, "makinelerin düşünme yeteneğine sahip olup olmadığı değil, makinelerin insanlar kadar yaratıcı 
olup olmadığı" sorusudur. Bu sorunun rehberliğinde, 2001 yılına gelindiğinde Selmer Bringsjord, Paul Bello ve David Ferrucci "Lovelace Test" adını verdikleri ve Turing Teste alternatif olarak geliştirdiklerini söyledikleri yeni bir yaklaşım geliştirmişlerdir. Onlar, Turing testin yapısının hile yapmaya dayalı bir test olduğunu, sistemle etkileşime giren insanları, bu sistemin gerçekten akla sahip olduğuna inandırarak kandırmaya çalıştıklarını belirtmektedirler. Onlara göre, akıllı bir sistem yaratıcı bir konsept ya da bir sanat eserini oluşturması gerekmektedir (Bringsjord vd., 2001: 3-6). Bu bakımdan oluşturdukları Lovelace Testiyle yapay zekanın yaratıcı özelliklerini sınayan yeni bir sistem oluşturdukları ifade edilmektedir.

2014 yılında ise Mark O. Riedl, Lovelace Testinin güncellenmiş bir versiyonu olan ve makinenin yaratıcıllı̆ı̆ı ı̈lçen "Lovelace 2.0" adlı Turing testine alternatif olarak bir test önermektedir. Riedl (2014) testi, "bir hesaplama sisteminin yaratıcı bir eser oluşturabileceği fikrine meydan okumak için tasarlanmış bir test öneriyoruz. Yaratıcı eylemlerin belirli bir alt kümesinin insan düzeyinde zeka gerektirdiğine inanıyoruz, bu yüzden hem yaratıcılık testi hem de zeka testi yapıyoruz." ifadesiyle tanımlamaktadır. Özetle Reidl'ın geliştirdiği "Lovelace 2.0" testi için makineyi yaratıcı bir eser ortaya koyması noktasında hem akıllı olup olmadığını değerlendiren, hem de yaratıcı olup olmadığını sorgulayan bir test geliştirdiğini söyleyebiliriz.

İspanya yapay zeka araştırmaları enstitüsü sorumlusu Ramón López de Mántaras, yeni teknolojiler ve özellikle yapay zekanın, yaratım sürecinin doğasını büyük ölçüde etkilediğini, bilgisayarları insan yaratıcılığına yardım etmek için bir araç olarak görmek yerine, kendi başına yaratıcı bir varlık olarak görebileceğimizi ifade etmektedir. $\mathrm{Bu}$ durumu hesaplamalı (computational) yaratıcılık adını verdiği yapay zekanın yeni bir alt dalı olarak tanımlamaktadır. Ona göre hesaplamalı yaratıcılık, "insanlar yaptığında yaratıcı sayılabilecek davranışlar sergileyen bir yazılım geliştirme çabasıdır. Bu tür yaratıcı yazılımlar, matematik teorilerini icat etmek, şiirler yazmak, resim yapmak ve müzik bestelemek gibi özerk yaratıc1 görevler için kullanılabilir. Bununla birlikte, hesaplamalı yaratıcılık çalışmaları için aynı zamanda insan yaratıcılığını anlamamızı ve yazılımın sadece bir araçtan ziyade bireyle yaratıcılık konusunda işbirlikçi bir yaklaşım sergileyerek yaratıcı insanlar için programlar üretmemizi sağlar." şeklinde açıklamaktadır (Mántaras, 2017: 2). Yine Vakratsas ve Wang (2020: 1-2) de, hesaplamalı yaratıcılığı yapay zekanın bir alt kolu olarak değerlendirmekte ve reklamda yaratıcılık ilişkisini araştırmaktadır. Onlara göre, hesaplamalı yaratıcılık alanındaki birçok çalışma, yaratıcılığı tanımlamak ve üretmek için yapay zeka kullanmayı amaçlamaktadır. Hesaplamalı yaratıcılığın iki niteliği, onu özellikle reklamcılık faaliyetleri için uygun ve ilgi çekici kılmaktadır. Bunlardan birincisi yapılandırılabilir ve işlenebilir olmasıdır. $\mathrm{Bu}$ sayede reklam yaratıcılığı konusunda üretken ve sistematik bir perspektiften yeniden düşünme firsatı sunmaktadır. İkincisi ise; otonom ve yarı otonom (insan desteğiyle) bir şekilde olması nedeniyle yaratıcı reklam fikrinin oluşturulmasını destekleyecek uygunlukta olmasıdır. Yapay zeka sistemlerinin yaratıcı reklam faaliyetlerinin üretimi sürecinde farklı aşamalarda otonom ve yarı otonom makineler halinde destek verdiği, yeni çözümler sunduğu çeşitli uygulamalarda görülmektedir.

Yapay zekanın yaratıcılık unsuru barındırarak görsel sanat ve tasarım ürünleri sergilediği sistemlerin başında ise, ilk olarak AARON akla gelmektedir. İngiliz ressam Harold Cohen'in 1973 yılında geliştirmiş olduğu AARON, bilinen en başarılı ve en iyi görsel sanat ürünleri üreten yazılımlardan biri olarak karşımıza çıkmaktadır. Cohen, AARON'u her aşamada yinelemeli bir tasarım süreci kullanacak biçimde çizimler oluşturmak üzere programlamıştır. Cohen, her aşamada programın çıktısını değerlendirmiş ve ardından programı, sonuçlar hakkındaki kendi estetik yargısını yansıtacak şekilde değiştirmiştir. Başlangıçta soyut çalışmalar yapan AARON, 
süreç içerisinde gelişerek, 1986 yılına gelindiğinde renkli çizimler yapmaya başlamıştır. Ardından üç boyutlu uzayda taşlar, çeşitli nesneler, hayvanlar, bitkiler ve insanlar gibi birçok objeyi tasarlamayı öğrenmiştir (Sawyer, 2012: 144-146). AARON, görsel sanatlar alanında yaratıcı çizimler ya da resimler yapmaya programlanmış, özgün, çevrimdışı ve etkileşimli olmayan ve son versiyonuyla kendi kendine üretim yapabilen bir yapay zeka sistemi olarak açıklanmaktadır.

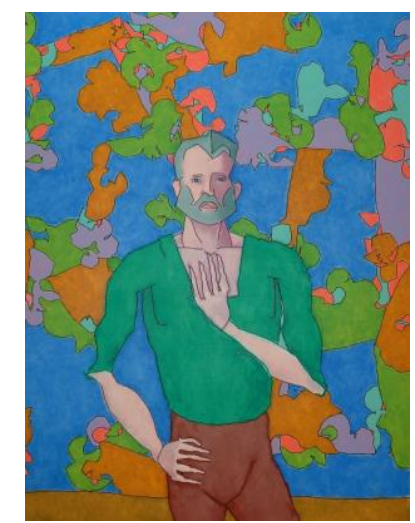

Kaynak: Cohen, H. (1992). https://flash---art.com/article/harold-cohen/, Erişim tarihi: 10.06.2020.

Görsel. 1 AARON'un tasarlamış olduğu insan figürü

Yapay zekanın görsel sanat ürünleri tasarladığı bir başka örnekse Simon Colton'un programladığı The Painting Fool adlı algoritmadır. The Painting Fool, AARON'dan çok daha özerk bir yapıya sahiptir. Program fiziksel olarak tuval üzerine boya uygulamasa da, birçok stili dijital olarak simüle etmektedir. (Mántaras, 2017: 17). The Painting Fool sadece asgari bir yönlendirmeye ihtiyaç duymakta ve kaynak materyal için web üzerinden çevrimiçi olarak kendi konseptini oluşturabilmektedir. Program konuyla ilgili kendi web aramasını yapmakta ve sosyal medya ağları üzerinden de bu taramayı gerçekleştirmektedir. Bu yaklaşım kitleler için anlam ifade eden bir sanatsal ürün üretmesine izin vermesi fikrine dayanır, çünkü yazılım web üzerinden hareket ederken, hisseden ve tartışan insan deneyiminden faydalanmaktadır (Colton vd., 2015: 193). Dolayısıyla yapay zekanın çeşitli kültürel deneyimlerden yararlanabileceği düşüncesi de kanıtlanmaktadır. 


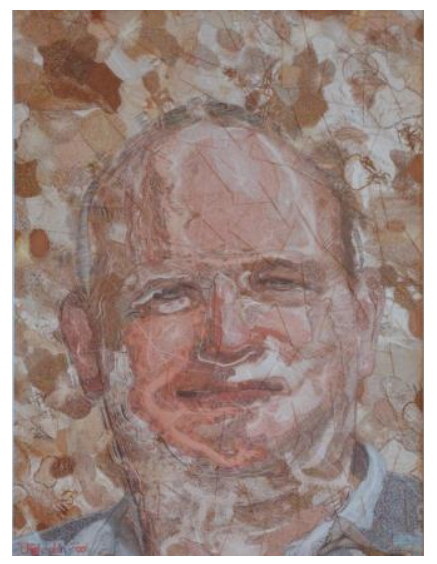

Kaynak: Colton, S. Halskov, J., Ventura, D., Gouldstone, I., Cook, M., Pérez-Ferrer, B. (2015). "The Painting Fool Sees! New Projects With the Automated Painter", Sixth International Conference on Computational Creativity s.189-196.

Görsel. 2 The Painting Fool'un tasarlamış olduğu portre çalışması

Colton (2012: 3), The Painting Fool yazılımı için, "bir gün kendi başına yaratıcı bir sanatçı olarak ciddiye alınacağını umduğumuz bir yazılımdır. Bu amaç, yol boyunca üstesinden gelinen teknik zorlukların yeni ve geliştirilmiş yapay genel zeka (AGI) tekniklerine yol açacağı umuduyla yapay zeka projesi olarak sürdürülmektedir. Ayrıca yaratıcı olarak kabul edilebilecek yazılımların etkisinin sanat dünyasında ve daha geniş kitlelerde test edildiği bir sosyolojik proje olarak da sürdürülmektedir.” yorumunu yapmaktadır.

Bu iki yazılımın ortak özelliklerini; kodlanmış çeşitli bilgileri, veri setlerini, parametreleri ve kombinasyonları kullanarak özgün sanat ve tasarım ürünleri oluşturabilmeleri şeklinde açıklanabilir. AARON, Cohen'in yaptığı programlamayla yıllar içerisinde yeni versiyonlarıyla birlikte gelişerek ürünler ortaya koymaktadır. The Painting Fool ise daha faklı ve kültürel olarak daha anlamlı parçalar üretmesini sağlayan, sanatçı ve tasarımcıların veya sıradan birinin, sistemin tüm yönleriyle yazılımı yeniden programlayabilmesine olanak sağlayan bir arayüze sahip olduğu söylenmektedir. The Painting Fool'u AARON'dan ayıran en önemli özellik webde tarama işlemiyle kendi veri tabanını oluşturabilmekte ve gereken veri kaynağını tespit edebilmektedir. $\mathrm{Bu}$ özelliği sayesinde bireye ihtiyaç duymadan kendini geliştirebilmesi ve tarayıcılar arası geçişler yaparak kullanıcının daha etkin olduğu çevrimiçi ortamlarda birden çok insanın sahip olduğu his ve birikimleri toplayarak bilginin daha kültürel olarak üretilmesine imkân tanımaktadır. Makinelerin bu denli yükselişiyle birlikte sanat ve tasarım alanlarında kullanılması, görsel tasarım anlayış ve uygulamalarının sayısal çıktılar anlamında değerlendirilmesini sağlamakta, yapay zekanın sürece dâhil olmasıyla birlikte yeni görsel tasarım uygulamalarının da oluşabileceği ön görülmektedir. Bu anlamda görsel tasarımla ilgili kavramsal bir çerçeve de çizmek gerekmektedir.

\section{Görsel Tasarım ve Yapay Zeka İlişkisi}

İnsanoğlunun varoluşundan bu yana bir iletişim enstrümanı olan görüntünün birçok aşamadan geçerek günümüzde bir görsel iletişim unsuru haline geldiği görülmektedir. Diğer taraftan milyonlarca insana erişilebilirliğin artmasının paralelinde bu çağda görüntünün de önem kazanmasıyla birlikte görmek ve görüneni tasarlamak giderek daha önemli bir süreç haline gelmektedir. Bunun nedenini ise, hayatın her alanında ve her aşamasında, her hangi bir konuyla 
ilgili görüntüyle karş̧laşabilme olasılığının giderek artması olarak açıklanabilir. Dolayısıyla görüntünün tasarlanmas1 sırasında en etkin uygulama metotlarının uygulanması önem kazanmaktadır. Bu bakımdan tasarım ve görsel tasarım konularının, geleceğe etki edeceği düşünülen unsurların yanında değerlendirmek gerekmektedir.

Etimolojik olarak, tasarım sözcüğ̈̈ Latince biçim vermek, temsil etmek anlamlarına gelen "designare" kelimesinden gelmektedir (Tunal1, 2004: 13). TDK sözlügüne göre ise: "zihinde canlandırılan "biçim, tasavvur", "bir sanat eserinin, yapının veya teknik ürünün ilk taslağı, tasar çizim, dizayn", "bir araştırma sürecinin çeşitli dönemlerinde izlenecek yol ve işlemleri tasarlayan çerçeve", "daha önce algılanmış olan bir nesne veya olayın bilinçte sonradan ortaya çıkan kopyası" olarak tanımlanmaktadır.

Tasarım, yaratıcılığı ve problem çözümünün her ikisini de bünyesinde barındıran bir süreçtir. İstenilen amaca cevap veren bir düşünceyi ifade eder. Anlaşılabilir bir bütünün parçalarının organizasyonudur. Belli bir amaca hizmet etmesi için, malzeme ve biçimden oluşan bir bütündür (Bevlin, 1977: 3-10'dan akt. Önlü, 2010: 86). Ketenci ve Bilgili (2006: 277)'ye göre ise tasarım kavramı; gerekli olanın araştırılması ve biçimlendirecek kişinin yaratıcı özelliklerini de katarak ortaya çıkardığı bir biçim, şekil veya modeldir. Tasarım kavramı, bu tanımlamalardan anlaşılacağı üzere problemin çözümüne yönelik, yaratıcı yöntemler sunmak anlamına gelen ve birçok disiplin tarafindan da kullanılan bir terim olduğunu söylemek mümkündür.

Tasarım kavramını "bir problemin çözümü" olarak değerlendiren Becer tasarım için; "bir model kalıp ya da süsleme yapmak olarak değerlendirilmemelidir. Bir tasarımın, kendi içinde bir yapıya ve bu yapı arkasında bir planlamaya sahip olması gerektiği düşünülmektedir. Bütün sanatların temelinde bir tasarım olgusu bulunmaktadır. Tasarlama eylemi oluşturulacak yapının organizasyonu ile ilgili her türlü faaliyeti içine almaktadır." ifadesini kullanmaktadır (Becer 2015: 32-34). Bernard (2002: 31)'1n "görülebilen ve iletişimsel ya da işlevsel bir amaç içeren şey" olarak tanımladığı tasarım kavramı için; kendi içerisinde oluşturduğu sistem gereğince var olan her türlü planlamanın oluşumunu destekleyen ve işlevsel olmak, iletişim kurmak gibi eylemleri de hedefleyen uygulamalar yöntemi olduğu söylenebilir.

Tasarım sürecinde ortaya konan ürün belirli bir amaca yönelik olmalı, bilinçli bir düşünce sonucu ortaya çıkarak işlevsel olmalı, alışılmışın ötesinde ve daha önce hiç yapılmamış ya da benzerlerinden çok farklı bir görsellikte, kendine has bir özellik taşımalıdır. Çalışma ya da ürün yaratı içermelidir (Önlü, 2010: 86). Tasarım; zihinde tasarlanan düşüncenin barındırdığı işlevsellik, iletişime yönelik ve yaratıcılık unsurlarını barındırmasıyla birlikte yaratıcısının tasarımıyla dışavurumunun ardından söz konusu estetiksel yapısıyla, izleyici/okuyucusunun algılarında etkileşime neden olan sanatsal bir eylem olarak da görülmektedir. Mozota tasarım sürecini, 4C adını verdiği temel dört etkenle açıklamaktadır. Bunlardan birincisi; yaratıcllık (Creativitiy); daha önce olmayan bir şeyin yaratılmasıdır. İkincisi karmaşıklık (Complexity); çok sayıda parametre ve değişken üzerindeki kararları içermektedir. Üçüncüsü uzlaşma (Compromise); bazen çatışan (maliyet ve verimlilik, estetik ve kullanım kolaylığı, malzemeler ve uzun ömürlülük gibi) unsurları dengelemeyi sağlamaktır. Sonuncusu ise, seçim (Choice), bir problemin temel konseptinden en ufak renk veya biçim detayına kadar her seviyede birçok potansiyel çözüm arasından seçim yapmayı gerektirmektir (Mozota, 2006: 29'dan akt. Güzeloğlu, 2012: 17). Bahsedilen bu dört kavram tasarım sürecinin yanıt bulması gereken temel etkenler olarak siralanmaktadır. 
Birçok disiplinde yer alan tasarım kavramının görüntüyü işleme sanatı olarak tanımlayabileceğimiz görsel tasarım hali; hayatımızın her alanında karşılaştığımız ve bizi bir şekilde etkileyen olgulardan biri olarak açıklanmaktadır. Günümüzde görsel tasarım uygulamaları öylesine yaygındır ki, teknolojinin de gelişimiyle birlikte gün içerisinde her alanda görsele maruz kalmamak imkânsız hale gelmektedir. Özdem (2006: 96)'e göre görsel tasarım dendiğinde ilk akla gelen, görülebilen ve izlenebilen her unsurun görsel olarak ifade ediliş şekli olduğunu, bu ifade şeklinin çok farklı biçimlerde ortaya çıkmakta ve bu nedenle görsel tasarım belirli alanlarla sınırlandırılamadığını belirtmektedir. Yine Özdem, görsel tasarımın işlevsel olması, izleyici/okuyucuyla iletişim kurması ve estetik kaygıları barındırması gibi unsurlara da vurgu yapmaktadir.

Görsel tasarım denince grafik ve onların iletişim yollarının aranması önem kazanmaktadır. Bu durum grafiklerin tasarımından basılı ve elektronik tasarım araçlarına kadar uzanan bir süreci işaret etmektedir. Burada bilgisayarların kullanımı ve görselin tasarımı sürecinde görüntünün yapısı ve anlamı gibi unsurlar yaratıcılık eyleminin kültürel çıktıları olarak karşımıza çıkmaktadır. Yaratıcılığı tetiklemek ve problemlerin çözümüne yönelik çözümler geliştirmek için görsel tasarım konusunda çeşitli çözümler geliştirilmelidir. Her tasarımcının bu konuda kendine ait çeşitli yöntemleri söz konusudur. Fakat günümüzde yapay zeka uygulamaları bu konuda programlanmış algoritmalar kullanarak ve makine öğrenimi yöntemiyle faaliyetlerinin çoğunu tekrarlayarak tasarım eylemi gerçekleştirmektedir. Bu anlamda tasarım amaçlı yapay zeka uygulamaları yaratıcılık unsuru barındıran ve diğer taraftan başlangıçta her hangi bir tasarım süreci olmaksızın çeşitli kültürel deneyim ve birikimlerden yararlanarak çalışabilmektedir.

Bugün yapay zeka ve makine öğrenme yöntemi ile çalışan birçok tasarım yazılımı söz konusudur. Artık görsel tasarım alanında ister görüntü işleme, ister sayfa, web ya da logo gibi vektörel tasarımlar olsun, yapay zekadan yararlanılan bir çok program mevcuttur. Fakat diğer taraftan her geçen gün gelişen yapay zeka uygulamalarıyla birlikte algoritmalar üzerinden çeşitli estetik kaygılar taşıyan tasarım uygulamalarını kendi başına oluşturan yapay zeka uygulamaları da görülmektedir. Bunlardan birisi de 2019 senesinde sanat hayatının 50. senesini kutlayan ve algoritmalar yazarak farklı konularda çeşitli sanatsal ürünler ortaya koyan Manfred Mohr'un çalışmalarıdır.
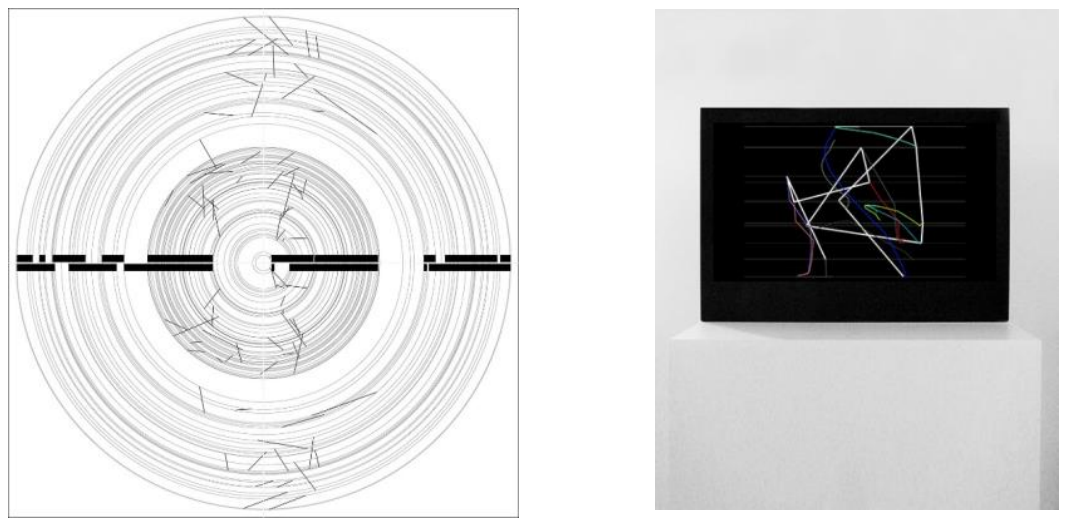

Kaynak: Mohr, M. (2019). http://www.emohr.com/ww4_out.html, Erişim tarihi: 11.07.2020.

Görsel. 3 Manfred Mohr’un Algoritmalarla Yapmış Olduğu Animasyonlardan Kesitler 
Mohr'un yapmış olduğu bu çalışmalara generatif sanat adı verilmekte ve generatif sanatla ilgili Al (2019: 80) şu ifadeleri kullanmaktadır. Sanatçının estetik anlayışı doğrultusunda belirlediği kuralların bilgisayar tarafından üretilmesi; görünmeyeni görünür kılarak güzelliğe ulaşma kaygısı taşıyan ve işlerinde öngörülemezlikten doğan şaşırtıcı unsurları, yeniliği ve bilgisayarların üretim sürecinin bir kısmını üstlenmesi bağlamında sanatçıyı özgürleştiren kontrol dışılığ tasavvur edilen sanat eserleri, sanatçının tanımladığı dinamik süreçlerin görsel tezahürleridir. Bitmiş eserler sanatçı tarafından tasarlanan süreçlerin gizeminin keşfedilmesini sağlarken, sanatçının benliğinin gizemli doğasını aydınlatan imgeler olarak hizmet eder.

Mohr'un algoritmik kodlar üzerinden tasarladıkları bu sanat eserlerini, yapay dar zekanın ortaya koyduğu ürünler olarak tanımlanmaktadır. Yapay zekanın tasarıma olan etkisi uzun süredir birçok araştırmacının ilgisini çekmekte ve konuyla ilgili farklı çalışmalar yapılmaktadır. Bilgisayarlar için ekran kartı tasarlayan NVIDIA firması ise yapay zekanın kusursuz işlem yapabilme özelliği nedeniyle görüntü işlemede yapay zekadan faydalanmakta ve konuyla ilgili birçok yatırım ve araştırma yapmaktadır. Bilgisayardan ekrana yansıyan görüntünün işlenmesinde yapay zekadan faydalanan NVIDIA, aynı zamanda NVIDIA GAUGAN adını verdikleri bir yapay zeka yazılımıyla, tasarımcılara görüntü işlemede yeni olanaklar sunmaktadır.

Adını Fransız ressam Gaugin ve algortima kelimesinin kısaltması olan GAN kelimelerinin birleşiminden alan bu program, 2019 yılında tanıtılmış bir demo versiyon olarak yayınlanmaktadır. Derin öğrenme metoduyla hazırlanan program için, Flickr sosyal ağındaki 1 milyon görselin tanıtılarak hazırlandığını vurgulayan Nvidia Derin Öğrenme Araştırmaları biriminin Başkan Yardımcısı Bryan Catanzaro (2019), programın içinde göl olan bir görsele dă̆ eklediğinizde su üzerinde bu dağın yansımasının olması gerektiğini bildiğini ve bunun bir boyama kitabındaki nesneleri boyamak gibi bir şey olduğunu ifade etmektedir. Gaugan'in bir demo uygulama olduğu ve üzerinde hala çalışmalar yapıldığı, gelecekte bu programın görsel tasarımın birçok uygulama alanında kullanılacağı ön görülmektedir. Aynı zamanda bu program ile ilgili Flickr'dan aldığı 1 milyon görüntüden oluşturduğu veri setiyle, ortaya koyduğu eserleri yaratıcılıkla oluşturduğu ve kültürel bir çıtı olarak meydana getirdiği söylenebilir.

Google firması 2016 yılında yapay zeka temelli bir grafik tasarım uygulaması olan AlphaGd'yi geliştirmiştir. AlphaGd müşterinin gereksinimlerine göre ilgili görsel tasarım formunu oluşturup, genel pazarın gereksinimleri doğrultusunda estetik öğeleri birleştiren ve tasarım elemanlarını uygun şekilde kullanabilen bir uygulamadır. Yapay zekanın güçlü fonksiyonlarından yararlanan Alpha Gd, şu an sadece var olan tasarım formlarını taklit etmekte ve bağımsız bir şekilde inovatif çözümler üretememektedir (Wu, 2020: 2). Gelecekte grafik tasarım dünyasında yapay zekadan yararlanan bu tür uygulamaların fazlasıyla kullanılacağı öngörülmekte ve tüm tasarım endüstrilerinin nasıl gelişeceği, tasarımcıların sektörde yer aldığ 1 pozisyon gibi konular ve pazarlamaya olan etkisi üzerine düşünülmesi gerektiği ifade edilmektedir.

Karaata (2018: 187-195) ise, yapay zeka ile çalışan ve grafik tasarım alanındaki uygulamaları aşağıdaki gibi sıralamaktadır:

- 2016 yılında hayata geçirilen, kurucusunun Dawson Whitfield olduğu, grafik tasarım uzmanı olmadan çeşitli yazı tipi, renk, sembol ve kompozisyonların karışımı aracılığıyla yeni bir logo oluşturan Logojoy adlı web site. 
- $\quad$ Trilyonlarca içerik ve veriden yararlanarak, yüksek çözünürlüklü görüntülerin yapay zekaya eklenmesinden ve müşteri tıklamalarının makineye öğretilmesine kadar belge ve pazarlama konusunda yıllar boyunca kullanılan bilgilerin birleştirilerek görüntü eşleştirme, yazı tipi türlerini tanımak gibi görüntüler üzerinde çeşitli çözümler üreten Adobe Sensei uygulamas1.

- $\quad$ Adobe, Microsoft ve NSERC firmaları tarafindan desteklenen, genel olarak grafik tasarım alanına yeni başlayanlar için geliştirilmiş ve mizanpaj, afiş, reklam tanıtım amacıyla kullanılabilecek tek sayfa görüntü tasarımları için interaktif çözümler sunan Design Scape uygulamasi.

- The Grid firması tarafından geliştirilen, web site tasarımı konusunda çözümler sunan Firedrop web sitesi.

$\mathrm{Bu}$ uygulamaların grafik tasarım alanına tasarımcıların yerini almasa da farklı çözümler getirdiği, zaman açısında bakıldığında ise hız kazandıracağı düşünülmektedir. Ayrıca yapay zekanın tasarımcılara yardımcı olarak çalışma süresinde harcanan zamanı kısaltmasına ve tasarımcıların yaratıcı süreçler için zaman kazanmasını sağlayacağı öngörülmektedir.

Uluslararası çevrimiçi dizi ve film içerik sağlayıcısı olan Netflix'de sistemin daha etkin ve verimli çalışması amacıyla yapay zekadan faydalanmaktadır. Netflix, büyük verinin ve yapay zekanın gücünden faydalanarak günümüz medya ortamını tamamen değiştirmiştir. Netflix'in çalışma prensibi veri ve yapay zeka merkezli bir işletim modeline dayanmaktadır. Kullanıcı deneyimini kişiselleştirmekten içeriklere verilen puanlardan gelecek yapımların nasıl olması gerektiğini belirlemeye kadar, verileri toplayan, eğiten ve işin neredeyse her yönünü yönlendiren algoritmaları yürüten yazılım altyapısı tarafından desteklenmektedir. Netflix 2010 yılında yapay zekadan yaralanmaya başlamış ve 2014 yılına gelindiğinde kullanıcı davranışını anlamaya yönelik kapsamlı yatırım yapma ve her kullanıcı için kişiselleştirilmiş bir yayın deneyimi geliştirme yaklaşımını genişletmiştir. Herhangi bir Netflix kullanıcısının gördüğü uygulama ekranları, bir makine tarafından "gerçek zamanlı" olarak tasarlanmaktadır. Sürecin başlangıcında birçok sınır ve parametre tasarımcılar tarafından belirlenmektedir. Ancak hangi filmlerin gösterileceği, nasıl gösterileceği, hangi resimlerle temsil edileceği ve diğer birçok tasarım kararı, yapay zeka problem çözme döngülerine yerleştirilmiş algoritmalar tarafından yapılmaktadır (Verganti vd., 2020: 216). Aynı zamanda Netflix kullanıcılara sunduğu film ve dizi içeriklerinden ilişkilendirdikleri görselleri kişiselleştirme biçiminde de algoritmalardan yararlanmaktadır. Netflix firması kullanıcı verilerinin analizi sayesinde, izleyicilerin zevk ve tercihlerinde muazzam miktarda çeşitliliğin olduğunu fark etmiştir. Dolayısıyla Netflix, her kullanıcıya bir filmin karelerinden çizilmiş, kendisi için özel olarak tasarlanmış bir kapak resmi gösterilmesine karar vermiştir. Ortaya çıkan film/dizi afişi kullanıcının özelliklerine yönelik tasarlanmaktadır (Chandrashekar, vd., 2017). Netflix ekibinin hangi film seçimini sunacağını ve ardından kullanıcı ile öneri arasındaki eşleşmeyi en üst düzeye çıkarmak için bu filmi nasıl bir afiş tasarımıyla sunacağını bulması karmaşık bir sorun oluşturmaktadır. Netflix’te bir dizinin tek bir sezonu yaklaşık 10 bölümden oluşmakta ve buda ortalama 9 milyon video karesine karş1lı gelmektedir. Yaratıcı editörlerin, izleyicinin dikkatini çekecek bir afiş tasarlamaları için bu kadar çok sayıda video karesini verimli bir şekilde incelemelerini istemek etkin bir çözüm olmayacaktır. Fakat yapay zeka bu tasarım problemini etkin bir şekilde çözebilmektedir (Verganti vd., 2020: 218). Netflix firması afiş tasarımını algoritmalar aracılığıyla belirli tasarım ilke ve elementlerini kullanarak kullanıcılardan edindiği veriler aracılığıyla kişiye en uygun tasarımı sağlamayı 
amaçlamakta böylelikle kullanıcıyla içerik arasındaki en etkin görsel iletişim tasarımı yöntemini uygulamayı hedeflemektedir.
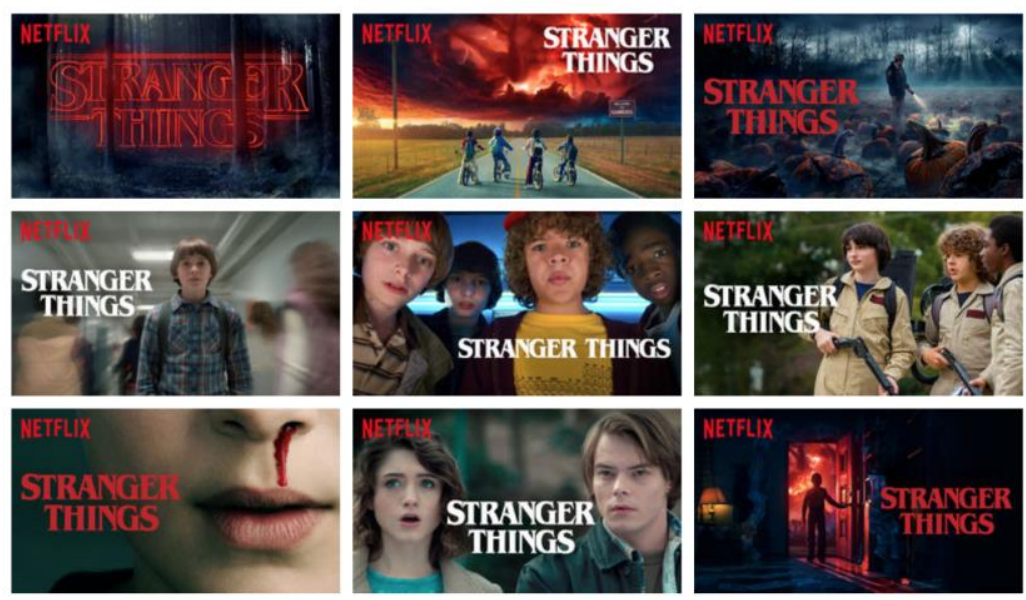

Kaynak: Chandrashekar, A., Amat, F., Basilico, J. \& Jebara, T. (2017). "Artwork Personalization at Netflix", https://netflixtechblog.com/artwork-personalization-c589f074ad76, Erişim tarihi: 25.03.2021.

Görsel. 4 Netflix'de yer alan Stranger Things dizisi afiş tasarımı örnekleri

Şu an Dördüncü Sanayi Devrimiyle (Endüstri 4.0) birlikte insanlık tarihinin en dinamik değişim dalgasının yaşandığını belirten Scwab ve Samans (2016), yapay zeka, arttırılmış gerçeklik, sanal gerçeklik, makine öğrenimi, bulut bilişim gibi sayısız fiziksel ve dijital teknolojinin bir araya gelerek birçok iş koluna etki edeceğini bunlar içerisinde sanat, tasarım, medya ve reklam uygulamaları gibi alanları da içereceğini belirtmektedir. Dolayısıyla yapay zekanın gelecekte hayatın her alanında etkili olacağı ve özellikle iş hayatında da büyük değişime neden olacağı bilinmektedir. $\mathrm{Bu}$ noktada henüz yeni başlayan bu adımların ileride tasarım dünyasına etkilerinin daha nelere olacağı konusu da merak edilmektedir. Tasarımcıların bu konuyla ilgili bakış açıları ve gelecek öngörüleri de farklılıklar gösterebilmektedir. Yaklaşık on altı yıldır görsel tasarım, ürün tasarım stratejisi, deneyim tasarımı, etkileşim tasarımı gibi birçok konuda çalışmalar yapan Miklos Philips, yapay zekayı bir büyü olarak nitelendirmekte, dünyayı kurtarmak için icat edildiğini ve insanoğlunu hem heyecanlandırdığını hem de korkuttuğunu belirtmektedir. Aynı zamanda yapay zekanın tam olarak anlaşılamadığını ve bu nedenle tasarım dünyasına etkisinin ne olacağının bilinemediğini belirtmektedir. Philips, tasarımcı tarafından temel bir tasarım oluşturulup, birkaç parametre sağlandıktan sonra yapay zeka sisteminin tasarımcıya bir dizi alternatif oluşturabileceğini ve tasarımcıda bu seçeneklerden en iyi tasarımı seçebileceğini ifade etmektedir. Öte yandan bahsedilen örnekler de yapay zekanın görsel tasarımla ilgili çeşitli uygulamalarda sürece etki ettiği görülmektedir. Bu noktada yapay zekanın özellikle görüntünün düzenlenmesi noktasında hesaplamalı yaratıcılık ve makine öğrenmesi gibi çeşitli alt alanlarından yararlanıldığı görülmektedir.

\section{Sonuç ve Tartışma}

Tarihsel süreç içerisinde insan ve araç arasındaki ilişkide yapay zekayla birlikte nesnenin ötesine geçilen bir durumla karşı karşıya olduğumuz ön görülmektedir. Yapay zekayla ilgili sağllk, ekonomi, savunma, sanat, spor vb. birçok alanda çeşitli icat ve buluşların üzerine 
çalışıldığı görülmektedir. Bu durum kimi zaman teknofobik bir bakış açısıyla distopik bir hayatın yorumlanmasına neden olsa da çoğu zaman insan hayatını olumlu yönde etki edecek birçok ürünün ortaya konduğu da görülmektedir.

Yapay zeka ile ilgili çalışmalar günden güne devam etmekte ve gelecekle ilgili çeşitli tezler ortaya atılsa da yapay zekanın yaratıcılık eylemiyle ilgili ilişkisi, kavramın başından beri dile getirilmiş sorulardan bir tanesi olarak karşımıza çıkmaktadır. Araştırmacılar, yapay zekanın gelişiminin dar, geniş ve süper olmak üzere üç evrede gelişim göstereceğini ve yapay süper zekanın insanoğlundan daha gelişmiş bir evre olarak karşımıza çıkacağını belirtmektedir. $\mathrm{Bu}$ durum hali hazırda araştırılan ve üzerinde testlerle sonuçlar elde edilmeye çalışılan yapay zekanın yaratıcılık eylemiyle ilgili başka soruları da beraberinde getirmektedir. 1950'li yıllarda başlayan serüven bugün yapay zekanın yaratıc1lık konusunda yetilerinin test edildiği ve insandan daha yaratıcı olabilen bir makine gerçekleştirilebilir mi sorularının yöneltildiği bir dönemi işaret etmektedir.

Yapay zekayla algoritmik resimler ortaya koyan Paris merkezli Obvious adlı sanat atölyesinin, 14. ve 20. yy. arasında yapılmış olan 15 bin resmin makineye tanıtılmasıyla oluşturulan Edmond Bellamy'nin Portresi adlı eserin 2018 yılında açık arttırmada 432.500 dolara satılması insanoğlunun yapay zekaya olan ilgisinin bir göstergesi sayılabilir. Makinenin daha önce kimseye ait olmayan bu portreyi çıkarması insanoğlu için merak uyandırıcı ya da ilgi çekici duygular uyandırabilir. Fakat şu ana kadar yapılan çalışmaların ardından makinelerin ona öğretilen dışında bir üretim gerçekleştirmesi ya da hayal etmesinin zor olduğunu söylenebilir. $\mathrm{Bu}$ durumu ise Fransız düşünür Pierre Levy (2018)'nin gelecekte yapay zekanın otonomlaşması düşüncesiyle ilişkilendirerek söylediği "insanın farklı çağlarda farklı nesneleri araçsallaştırmasının yalnızca bir tezahürü olarak yorumlanabilir" cümlesini akla getirmektedir. Bir teknoloji teorisyeni olan Levy (2018), yapay zekanın gelecekte otonomlaşması düşüncesini homosapiens'ten bu yana insanoğlunun çeşitli nesneleri araçsallaştırmasından öte bir şey olmadığını ve asıl yapay zekanın insanoğlunun zekası olduğunu ifade etmektedir. Bunun nedenini yapay zekanın çeşitli verileri kaydetmesi durumu insanın yazının icadıyla birlikte başlayan ve kütüphane, telefon, telgraf, televizyon, bilgisayar ya da algoritmalar gibi araçlarla kaydetmeye başlamasıyla eş değer ve daha eski olduğunu belirtmektedir. Özetle Levy açıklamasında, insanın icat ettiği yapay zekanın daha önce icat ettiği araçlardan bir farkı olmadığını, asıl insan aklının nesilden nesile gelen bilgi dağarcığının çeşitli depolama alanları sayesinde cisimleşerek, yapay zekaya dönüştüğünü ifade etmektedir.

Öte yandan yapay zeka görüntülerdeki nesneleri algılama, bireyin konuşmasını anlama ve cevaplama, oyun oynama, çeviri yapma, resim yapma, font üretimi, fotoğrafta bulunan objenin arka planını silme gibi insanlarla kıyaslanabilir yetenekler geliştirdiği gözlemlenmektedir. $\mathrm{Bu}$ durumu ele aldığımızda tasarım fikrinde, tasarım faaliyetlerinde ya da genel yaratıcı süreçte rol oynayabilir mi sorusunu sormanın gerekli olduğunu düşündürmektedir. Teknik dünyasının, en ilkel aletlerden, araç ve gereçlerden en yetkin makinelere, bilgisayarlara kadar geniş ve zengin bir tasarım dünyasını sergileyeceğini ifade eden Tunalı (2004: 21)'ya göre teknik; ars, insanın doğada hazır olarak bulunmadığı, ama entelektüel, tinsel varlığından doğaya kattığı yapay bir bir varlıktır. $\mathrm{Bu}$ fikirden yola çıkılarak teknik ürünün, araç ve gereçlerle sanat-tasarım ürünleri arasında bir ilişki olduğu ve Baudrillard (2011: 45)'ın çevremizde simülasyonların ürettiği hipergerçek, gerçeğin her yerde şaşırtıcı biçimde ona benzemesine neden olduğu düşüncesiyle ilişkilendirildiğinde teknik araçların üretime katılması ve tasarıma olan etkisinin birer simüle edilmiş gerçekten oluşan görüntüleri ürettiği görüşü de ifade edilmektedir. Günümüz yapay zeka 
uygulamalarının algoritmalar sayesinde teknik bir araca dönüştüğünü ve oluşturulan ürünün yaratıcılıkla ilişkilendirilebilen hipergerçek görüntüler olduğu görüşü çıkarılmaktadır. Yine Baudrillard (2018: 20-21), çevremizdeki görüntüler son derece hızlı bir dolaşım ve olanaksız bir mübaledenin eseri olduğu ve hızla çoğalmanın yaşandığını ifade etmektedir. Bu çağda buna imkan tanıyan en önemli metanın teknik olarak kullanılan yapay zekanın yaratmış olduğu görüntüler olduğu belirtilmektedir.

Diğer taraftan sanatla ilgili olarak durağan ya da değişmeyen her hangi bir şeyle karş1 karşıya olunmadığını, bir sanat biçimi ya da tarzının, varolan uzlaşımları yıkabileceğini ve izleyicilere belirsiz gelebileceğini fakat zamanla kendi uzlaşımlarının sağlanacağını savunan Claude Shannon'un enformasyon kuramından yola çıkarak yapay zekayla oluşturulan çeşitli görüntülerin günümüz toplumları için bir belirsizlik algısı yaratabileceğini fakat estetiksel açıdan tasarımın taşıması gereken çeşitli unsur ve yaratıcılık yetisinin oluşturulabileceği vurgulanmaktadır (Fiske 2003: 30). Dolayısıyla enformasyonlar aracılığıyla öğrenen algoritmik sistemler olan yapay zekanın görsel ürünlerinin, kültürel açıdan da kabul edilebilirliğinin olduğu nitelendirilmektedir. Yaratıcılık ve teknoloji arasındaki ilişkinin geçmişe göre daha fazla olmasının dijital teknolojilerin günlük hayata bu denli girmesiyle yaşanan dijitalleşme nedeniyle olduğu açıktır. Elektronik sistemler sayesinde imge tabanlı metafor yardımı ile algoritmik kodlarla üretilen görüntüler, bireyle etkileşim halinde olan bir organizmaya dönüşmektedir (Kuspit, 2012). Bu bakımdan teknoloji aracılığıyla oluşturulan enformasyonun yaratıcı çözümler sunarak toplumsal çıktılar sunması, dijitalle olan etkileşimden kaynaklanmaktadır. Öte yandan yapay zekanın alt kolları olarak ifade edilen yaratıcık unsurunu açıklayan çeşitli özelliklerin Enformasyon Kuramında ifade edilen estetiksel niteliklere karş1lık geldiği görülmektedir.

Meslek olarak bakıldığında insana kıyasla hata yapma olasılığının daha düşük olması, yapay zekanın tercih edilmesi anlamında avantaj sağlayabileceğini söylenebilir. Bu durum aynı zamanda yapay zekanın tasarım eylemi öncesi yaratım sürecini beklemeksizin işlem yapma özelliğinden dolayı hız ve zaman açısından da büyük avantaj sağlayabilir. Fakat diğer taraftan tasarım mesleğinde insana ihtiyaç kalmaması durumu da mümkün olabilecektir. Ayrıca araştırmacıların yapay zekanın yaratıcılığıyla ilgili geliştirdikleri çeşitli test yöntemleri de yapay zekanın yaratıcı çözümler ortaya koyabileceğini de öngörmektedir.

Manovich (2018: 3)'e göre yapay zekanın kökeni bilişsel otomasyondur ve ileride kazanacağı yetileri süper-bilişsel şeklinde ifade ettiği daha gelişmiş bir paradigmada sürdürecektir. Dolayısıyla insanlar yapay zekanın son yıllardaki büyük başarıları hakkında konuştuklarında, kullanılan örnekler alanın başlangıcında onlarca yıl önce tanımlanan; doğal konuşma anlayışı, otomatik çeviri ve fotoğraflardaki nesnelerin tanınması gibi aynı görevlerdir. Fakat belki de daha az belirgin olan şey, yapay zekanın kültürel yaşamlarımızda ve davranışlarımızda eşit derecede önemli rol oynadığı ve estetik yaratım ve estetik tercih süreçlerini giderek otomatikleştirmesidir.

Manovich, konuya estetik yaratımların kültürle olan ilişkisine de değinerek dijital çağ olarak adlandırdığı bu döneme yapay zekanın ne gibi etkileri olabileceğini çeşitli sorularla dile getirmektedir. Bunlar: "yapay zekanın kültürel üretime entegrasyonu estetik değişkenliğin azalmasına yol açar mı?, ya da tam tersine arttırır mı?. Dahası estetik değişkenliğin tanımlanmasının ve ölçülmesinin farklı yolları nelerdir?" gibi sorulardır. O, özellikle son soruyu kendi içerisinde daha üretken bir soru olarak görmekte ve dijital çağda estetik hakkında yeni düşünme yolları açabileceğini belirtmektedir (Manovich, 2018: 18). Manovich'in bu yorumlarının ardından yeni dönemde yapay zekanın insanoğlunun estetik anlayışına ve çeşitli 
değişkenlerine de etki edeceğini, bu anlamda estetik anlayışın sağladığı kültürel çıktıların değişime uğrayabileceği düşüncesiyle tekrar gözden geçirilmesi gerekmektedir.

Görsel tasarım uzmanının üretim biçimi, toplumsal sembollere dayalı imgelem ve tasarımc1-dağıtıcı-okuyucu/izleyici yoluyla çağın sunduğu imkânlar doğrultusunda dijital olarak kurgulanabilmektedir. Günümüzde teknolojik gelişmeler ve tasarımcının işbirliğiyle yapay zekanın katkı sunduğu çıktılar alınabilmektedir. Fakat gelecekte tasarımcının tamamen süreçten ayrılarak yapay zekaların işin başına geçtiği bir dönemi işaret etmek şu an için hayalden öteye gidememektedir. Diğer taraftan araştırmacıların aklından geçen ya da konuşup üzerine tartıştığı konuların içinde barındırdığı sorulardan biri olduğu da göz ardı edilmemelidir.

\section{Kaynakça}

Akın, L. H. (2008). "Yapay Zekâ ve Robotlar”, Bilim ve Teknik Dergisi, Ocak, s.36-38.

Al, B. (2019). "Generatif Sanat Kavramı ve Görsel Sanatlarda Sayısal Yaratıcılık", Tasarım Enformatiği Dergisi, İstanbul: Mimar Sinan Güzel Sanatlar Üniversitesi, 1(2), s.78-91.

Aslan, A. E. (2001). "Kavram Boyutunda Yaratıcılık” Türk Psikolojik Danışma ve Rehberlik Dergisi, Cilt:2, Say1:16, s.15-21.

Baudrillard, J.(2018). Kötülüğün Şeffaflı̆̆ı. (Çev. Işık Ergüden). 7. Baskı. İstanbul: Ayrıntı Yayınları.

Baudrillard, J. (2011). Simülakrlar ve Simülasyon. (Çev. Oğuz Adanır), 6. Baskı, Ankara: Doğubatı Yayınevi.

Becer, E. (2015). Iletişim ve Grafik Tasarım, Onuncu Baskı, Ankara: Dost Yayınevi.

Bevlin, E. M. (1977). Design Through Discovery, Newyork: Holt Rinehart and Winston.

Bringsjord, S., Bello, P., \& Ferrucci, D. (2001). "Creativity, the Turing Test, and the (better) Lovelace Test”, Minds and Machines, 11, s.3-27.

Boden, M. (2004). The Creative Mind: Myths and Mechanisms, London: Routledge.

Cevher, E. \& Aydın, Y. (2020). Yapay Zekanın Şafağında Sinema: Morgan Filmi Fragmanı Örneği, Gümüşhane Üniversitesi İletişim Fakültesi Elektronik Dergisi (e-gifder), 8 (1), 614-642.

Chandrashekar, A., Amat, F., Basilico, J. \& Jebara, T. (2017). "Artwork Personalization at Netflix”, https://netflixtechblog.com/artwork-personalization-c589f074ad76, Erişim tarihi: 25.03.2021.

Cohen, H. (1992). https://flash---art.com/article/harold-cohen/, Erişim tarihi: 10.06.2020.

Colton, S. Halskov, J., Ventura, D., Gouldstone, I., Cook, M., Pérez-Ferrer, B. (2015). “The Painting Fool Sees! New Projects With the Automated Painter", Sixth International Conference on Computational Creativity s.189-196.

Colton, S., (2012). “The Painting Fool Stories from Building an Automated Painter", Computers and Creativity, der. J. McCormack ve M. d'Inverno, Germany: Springer Berlin Heidelberg, s.3-38.

Davidson, L. (2019). "Narrow vs. General AI: What's Next for Artificial Intelligence?", https://www.springboard.com/blog/narrow-vs-general-ai/, Erişim tarihi: 12.03.2020. 
Fiske, J. (2003). İletişim Çalışmalarına Giriş. (Çev. Süleyman İrvan), 2. Baskı, Ankara: Bilim ve Sanat Yayınları.

Gartenhaus, A. R. (2000). Yaratıcı Düşünme ve Müzeler. (Çev. Ruhiser Mergenci ve Onur Bekir), Ankara: Ankara Üniversitesi Çocuk Kültürü Araştırma ve Uygulama Merkezi Yayınları.

Guo, Y., Liu, Y., Oerlemans, A., Lao, S., Wu, S., \& Lew, M. S. (2016). "Deep Learning for Visual Understanding: A Review”, Neurocomputing Volume, 187, 27-48.

Güzeloğlu, C. (2012). Basılı Reklamlarda Görsel Tasarım Yönetimi: Ödül Almış Basın Reklamlarının Görsel Tasarım Analizi, Yayınlanmış Doktora Tezi, İzmir: Ege Üniversitesi, Sosyal Bilimler Enstitüsü, Reklamcılık Anabilim Dalı.

Jajal, T. D. (2018). "Distinguishing Between Narrow AI, General AI and Super AI", https://medium.com/@tjajal/distinguishing-between-narrow-ai-general-ai-and-super-aia4bc44172e22, Erişim tarihi: 15.04.2020.

Kaplan, A., \& Haenlein, M. (2019). "Siri, Siri, in My Hand: Who's the Fairest in the Land? On the Interpretations, Illustrations, and Implications of Artificial Intelligence", Business Horizons, 62(1), s.15-25.

Karaata, E. (2018). “Usage of Artificial Intelligence in Today's Graphic Design”, Online Journal of Art and Design, 6(4), s. 183-198.

Ketenci, H. F., \& Bilgili, C. (2006). Görsel İletişim ve Grafik Tasarımı, İstanbul: Beta Basım Yayın.

Kuspit, D. (2012). "The Matrix of Sensations", http://www.artnet.com/magazineus/features/kuspit/kuspit8-5-05.asp, Erişim tarihi: 17.03.2021.

Levy, P. (2018). "Pierre Lévy takipçilerimizden gelen soruları cevaplıyor" (Yapay zeka üzerine), https://www.youtube.com/watch?v=VP3g60nE1-c\&feature=youtu.be, Erişim tarihi: 12.07.2020.

Luger, G.. F., \& Stubblefield, W. A. (1998). Artificial Intelligence: Structures and Strategies for Complex Problem Solving, Massachusetts: Addison Wesley Longman.

Malcolm B. (2002). Sanat, Tasarım ve Görsel Kültür, Ankara: Ütopya Yayınları.

Manovich, L. (2018). AI Aesthetics, Russia: Strelka Press.

Mántaras, R. L. D. (2017). "Artificial Intelligence and the Arts: Toward Computational Creativity”, $\quad$ https://www.bbvaopenmind.com/wp-content/uploads/2017/01/BBVAOpenMind-Artificial-Intelligence-and-the-Arts-Toward-Computational-CreativityRamon-Lopez-de-Mantaras.pdf, Erişim tarihi: 13.06.2020.

May, R. (2008). Yaratma Cesareti, çev. Alper Oysal, İstanbul: Metis Yayınları.

McCarthy, J. (2007). "What is Artificial Intelligence?", http://jmc.stanford.edu/articles/whatisai/whatisai.pdf, Erişim tarihi: 07.04.2020.

McCorduck, P. (2004). Machines Who Think, Massachusetts: A. K. Peters, Ltd. 
Miklos P. (t.y.). "The Present and Future of AI in Design (with Infographic)", https://www.toptal.com/designers/product-design/infographic-ai-in-design, Erişim tarihi: 12.07.2020.

Mohr, M. (2019). http://www.emohr.com/ww4_out.html, Erişim tarihi: 11.07.2020.

Mozota, B. B. D. (2006). Tasarım Yönetimi, çev. Sibel Kaçamak, İkinci Baskı, İstanbul: MediaCat Yayınları.

Nilsson, N. J. (1998). Artificial Intelligence A New Synthesis, China: Morgan Kaufmann Publishers, China Machine Press.

"Nvidia", (2019). "GauGAN: Changing Sketches into Photorealistic Masterpieces", https://www.youtube.com/watch?v=p5U4NgVGAwg\&t=40s, Erişim tarihi: 11.07.2020.

“Obvious AI \& Art”, https://obvious-art.com/portfolio/edmond-de-belamy/, Erişim Tarihi: 12.07.2020.

Önlü, N. (2010). “Tasarımda Yaratıcılık ve İşlevsellik Tekstil Tasarımındaki Konumu”, Atatürk Üniversitesi Sosyal Bilimler Enstitüsü Dergisi, 3 (1). S.85-95

Özdem, O. Ö. E. (2006). Açıkhava Reklam Ortamlarında Görsel Tasarım, Yayınlanmış Yüksek Lisans Tezi, İzmir: Ege Üniversitesi, Sosyal Bilimler Enstitüsü, Reklamcılık Anabilim Dal1.

Pirim, H. (2006). "Yapay Zeka", Journal of Yaşar University, 1(1), s.81-93.

Rield, M. O. (2014). "The Lovelace 2.0 Test of Artificial Intelligence and Creativity", https://arxiv.org/abs/1410.6142, Erişim Tarihi: 18.05.2020.

Russell, S., \& Norvig, P. (2010). Artificial Intelligence: A Modern Approach, USA: Prentice Hall Series.

Samurçay, N. (1983). “Zeka ve Yaratıc1l1k”, Eğitim ve Bilim Dergisi, 8(45), s.4-12.

San, İ. (1979). "Yaratıcılık, İki Düşünme Biçimi ve Çocuğun Yaratıcılık Eğitimi”, Ankara Üniversitesi Eğitim Bilimleri Fakültesi Dergisi, 12(1-4), s.177-189.

Sawyer, R. K. (2012). Explaining Creativity: The Science of Human Innovation, Second Edition, New York: Oxford University Press.

Shannon, C., E. (1948). "The Lattice Theory of Information", https://ieeexplore.ieee.org/stamp/stamp.jsp?tp=\&arnumber=1188572, Erişim tarihi: 17.03.2021.

Schwab, K. \& Samans, R. (2016). “The Future of Jobs: Employment, Skills and Workforce Strategy for the Fourth Industrial Revolution". Global Challenge Insight Report, World Economic Forum, Geneva.

TDK, "Yaratıcılık", www.sozluk.gov.tr, Erişim tarihi: 09.05.2020.

TDK, “Tasarım”, www.sozluk.gov.tr, Erişim tarihi: 01.07.2020.

Tunalı, İ. (2004). Tasarım Felsefesine Giriş. İkinci Baskı, İstanbul: Yapı Yayın.

Turing, M. A. (1950). “Computing Machinery and Intelligence”, Mind, 59(236), s.433-460. 
Vakratsas, D. \& Wang, X., S. (2020). “Artificial Intelligence in Advertising Creativity”, Journal of Advertising, https://doi.org/10.1080/00913367.2020.1843090.

Verganti, R., Vendraminelli, L. \& Iansiti, M. (2020). "Innovation and Design in the Age of Artificial Intelligence", J PROD INNOV MANAG, 37(3), s.212-227.

Wu, S. (2020). "Development of Graphic Design Based on Artificial Intelligence", Journal of Physics: Conference Series, ICAIIT 2020, doi:10.1088/1742-6596/1533/3/032022. 